\title{
Comparison Of The Implementation Of Pre-Court Process Before And After The Constitutional Court Decision Number: 21 / PUU-XII / 2014 In The Batang State Court
}

\author{
Moch. Isa Nazarudin ${ }^{1}$ and Umar Ma'ruf ${ }^{2}$
}

Abstract. The purpose of this study is to describe and analyze the basis of the court's authority to examine and decide on pretrial lawsuits, analyze and describe the legal force of pretrial decisions regarding the illegitimacy of determining criminal suspects and describe the comparative implementation of pretrial proceedings before and after the Constitutional Court ruling Number: 21 / PUU-XII / 2014 in the Batang State Court

This research uses descriptive research type with sociological juridical and normative juridical, data collection method with literature study, observation and content analysis.

At the end of the study the authors concluded that although the Constitutional Court's decision was indeed final and binding and binding and legal remedies could not be made anymore (a final decision). However, that does not mean automatically changing the Criminal Procedure Code. Because these changes can only be made by official institutions appointed by the State, namely the President and the Parliament which are the state's decision. Pre-trial objects prior to the enactment of the Constitutional Court Decision Number: 21 / PUU-XII / 2014, consisting of: whether or not a forced act of force (in the form of: arrest, detention, search and seizure); the validity of the termination of the investigation or the termination of the prosecution; and compensation or rehabilitation of pretrial objects after the entry into force of the Constitutional Court Decision Number: 21 / PUU-XII / 2014, namely the addition of a pretrial object over the validity of determining the suspect. In addition, the implications of the a quo Constitutional Court ruling also affect the validity of arrest and the validity of detention must be based on the objective requirements of the investigator; through two pieces of evidence and an examination of a prospective suspect in order to fulfill the allegation of "preliminary evidence, sufficient preliminary evidence, and sufficient evidence".

Keywords: Pretrial; MK Decision; Pretrial Object.

\section{Introduction}

The development of law in Indonesia itself is very dynamic and always changes following developments in society, legal developments, especially in the development of criminal (material) and criminal procedural law (formal) outside of the Indonesian Penal Code (Criminal Law Book) and the Criminal Procedure Code (Book Indonesian Criminal Procedure Law) currently in force. This is due to the basic rules of the Criminal Code (material) of the Criminal Code and Criminal Procedure Code (formal) of the Criminal Procedure Code which is an old legal product that has not yet been updated

\footnotetext{
1 Student of Master of Law, Sultan Agung Islamic University (UNISSULA), Semarang, email: nazarhakim2706@gmail.com

${ }^{2}$ Lecturer of Master of Law, Sultan Agung Islamic University (UNISSULA), Semarang
} 
or revised, only a revision / material test of the articles in the two laws and regulations did not replace / revise the entire KUHP or KUHAP.

For the Criminal Code (KUHP) / Act No. 1 of 1946 itself is a product of hereditary law or can be considered as a "biological child" from the Dutch Criminal Code which was enforced in the past colonial period and until now there has been no significant changes to the criminal law. For the Criminal Procedure Code (KUHAP) No. 8 of 1981 is a legal product that was produced during the New Order which was previously in the implementation of criminal procedure law in Indonesia using HIR (Herzine Inlandsch Reglement).

But we should be thankful that the birth of the Criminal Procedure Code is based on two reasons, namely the reason for creating a provision that can support the implementation of a fair criminal trial and the reason for urgency to replace the colonialist procedural law products as stated in the HIR (Herzine Inlandsch Reglement). ${ }^{3}$

The Criminal Procedure Code (KUHAP), known as Act No. 8 of 1981, State Gazette Number 76, entered into force on December 31, 1981. The Criminal Procedure Code contains provisions concerning procedures, procedures, and the requirements that must be obeyed and implemented in an effort to uphold law and justice and protect human rights. ${ }^{4}$ The Criminal Procedure Code is a legal code that regulates how to proceed or administer the Material Criminal Law, so that the judge gets a decision and how the contents of the decision must be implemented. In the judicial process, law enforcement officials use the Criminal Procedure Code as a guideline or reference for carrying out their duties. Not only that, the implementation of each of the articles contained in the Criminal Procedure Code is very important.

The main principle or difference in principles used between HIR and KUHAP is that HIR uses the principle of the Presumption of Guilt (ie, the presumption of guilty), namely justice seekers who are still suspects or defendants, since the first stage at the level of a priori investigation is considered an unforgivable criminal his sin while the Criminal Procedure Code uses the presumption of innocence principle that every person suspected, arrested, detained, prosecuted or confronted before a trial, must be presumed innocent until there is a court decision stating his guilt and obtaining permanent legal force. The Criminal Procedure Code has appointed and placed a suspect or defendant in an "equal" position, as a being of God who has a full human dignity. ${ }^{5}$

The formulation of the problem in this research is What is the basis of the court's authority to examine and decide on a pretrial lawsuit ?; What is the legal force of the pretrial ruling regarding the illegitimate determination of the suspect? How do you compare the implementation of the pretrial process before and after the decision of the Constitutional Court Number: 21 / PUU-XII / 2014 in the Batang State Court?

\footnotetext{
${ }^{3}$ Department of Justice. Decree of the Minister of Justice Concerning Guidelines for Implementing the Criminal Procedure Code. Minister of Justice Decree No. M.01.07.03 of 1983, as written by Adnan Buyung Nasution in his writing about pretrial vs commissioner judge in the National Law Commission Newsletter

${ }^{4}$ L\&J Law Firm, 2009, Bila Anda Menghadapi Masalah Hukum (Pidana), Forum Sahabat, p. 3

${ }^{5} \mathrm{M}$. Yahya Harahap, SH. Pembahasan Permasalahan dan Penerapan KUHAP Penyidikan dan Penuntutan.Sinar Grafika. Jakarta, 2013., p.11
} 


\section{Research Methods}

This research is a descriptive study. That is the type of research method that seeks to describe and interpret objects according to what they are. Descriptive research is also often called non-experimentation, because in this study researchers did not control and manipulate research variables. The method of approach used by the author is a sociological juridical approach, by examining the rules, concepts, community views, legal doctrines obtained from secondary legal materials, as well as the applicable laws and regulations relating to the problem of the constitutional court's decision on pretrial.

Data collection techniques with library research and interviews. The analysis technique used in this study is a qualitative analysis with an Interactive model.

\section{Results And Discussion}

\subsection{The Basic Authority of the Court to Examine and Resolve Pretrial Lawsuits}

Pretrial is an interesting thing to discuss, because pretrial is an institution whose role is to carry out horizontal supervision of every action taken by law enforcement officials at the level of investigation and prosecution. Article 77 of the Criminal Procedure Code (KUHAP) states that:

The district court has the authority to examine and decide in accordance with the provisions stipulated in this law concerning:

- The validity of arrest, detention, cessation of investigation or cessation of prosecution;

- Change losses and or rehabilitation for people whose criminal cases have been stopped at the level of investigation or prosecution;

In this provision it is clear that what can be applied for pretrial is legal or not arrest, detention, cessation of investigation or prosecution, and compensation and or rehabilitation. However, in practice, the court granted the pretrial petition outside of what was stipulated in article 77 of the Criminal Procedure Code.

The Constitutional Court accepted the petition for judicial review of Article 77 letter a of the Criminal Procedure Code which was filed by Bachtiar Abdul Fatah recorded in case number 21 / PUU-XII / 2014. Basically Bachtiar Abdul Fatah requested a judicial review of the limited pretrial authority which could not fully provide adequate protection to a suspect from human rights violations committed by investigators, and public prosecutors. The limitative nature of pretrial authority that does not cover all forced efforts carried out by investigators and public prosecutors is contrary to the principle of due process of law because a number of forced efforts that reduce human rights cannot be tested for validity through pretrial institutions.

Act No. 8 of 1981 concerning the Criminal Procedure Code (KUHAP), has governed limited and not as extensive pre-trial authority as Pre Trial Hearing in America or Rechter Commissioner in the Netherlands. In the Pre Trial Hearing, besides examining the forced efforts made by law enforcement officers, it also tested whether the public prosecutor had enough evidence so that the case could be submitted to the court. Likewise, the Rechter Commissioner who has broader authority, besides determining 
whether the arrest, detention and confiscation is legal, also conducts a preliminary examination of a case.

Pretrial judges expressly state in their legal considerations whether or not the determination of the suspect is valid or not included in the pretrial object, on the grounds that it is not regulated well in the Criminal Procedure Code, particularly Article 1 number 10 jo. Article 77 jo. Article 82 paragraph (1) jo. Article 95 paragraph (1) and paragraph (2), as well as in special criminal legislation that applies as positive law in Indonesia. However, the absence of provisions governing whether or not a legal examination of the determination of a suspect is part of the pretrial authority does not make the judge directly reject the proposed pretrial application.

The Judicial Power Law regulates the prohibition of judges from rejecting a case on the grounds that the law is absent or unclear, and the obligation of the judge to follow and understand the values of law and justice in society, as stipulated in Article 10 paragraph (1) and Article 5 paragraph (1 ) Act No. 48 of 2009 concerning Judicial Power.

Based on these provisions, the pretrial judge then made a legal discovery. In its consideration the pretrial judge stated:

"Considering, that the prohibition for Judges refusing to examine, try and decide on a case on the pretext or the reason that the law does not exist, of course gives birth to the authority given to the Judge to establish a law that originally did not exist to exist or whose original law was unclear becomes clear ; Considering, that the Judge's authority to establish a law that originally did not exist came into being, using the legal discovery method (recht finding), which if examined scientifically (scientifically) and legally must be accounted for; Considering, that the Judge's authority to determine the law which was originally unclear is clearly made using the method of interpretation (interpretation).

Based on the above analysis, the "legal discovery" by a pretrial judge who includes the determination of the suspect as part of the object that can be processed according to the provisions of Article 77 letter a of the Criminal Procedure Code is a mistake. Even if this is done, it means that the judge has already carried out the construction, added a new object norm element in the series of Article 77 letter a of the Criminal Procedure Code. Meanwhile, the addition is contrary to the ratio established by the formulation of article 77 of the Criminal Procedure Code.

Author's analysis from the description above that the basis of the court's authority to examine and decide on a pretrial lawsuit is Article 1 point 10 and Article 84 paragraph 1 of the Criminal Procedure Code which states that the District Court has the authority to adjudicate all cases concerning criminal acts committed in its jurisdiction. In this case the district court has the authority to examine and decide on a pretrial lawsuit to assess the validity of the detention, confiscation, cessation of the investigation or cessation of prosecution by the investigator or general public, whose examination authority is given to the Pre-trial. In dropping the verdict, the judge must state explicitly the basis of the ruling and the rationale / consideration of the ruling, as well as the consequences of ratification or non-ratification of pretrial reasons.

\subsection{The Legal Strength of the Pretrial Decision Regarding the Invalidity of Determination of the Suspect}


The legal force of the pretrial ruling regarding the illegality of the determination of the suspect legislation that can lead to an orderly and orderly life. Pretrial is part of a district court which is held to provide protection for the basic rights of a suspect or defendant in a criminal court so that supervision is carried out by a judge. This is in line with the demands of the times that requires judges to have an active role in criminal justice for the sake of upholding the law and justice and it is hoped that judges can carry out their duties fairly and impartially and provide protection for human rights especially those concerned in criminal justice.

Pretrial aims to uphold the law, legal certainty and protection of the rights of suspects because according to the Criminal Procedure Code, every act of forced effort must be in accordance with the provisions stipulated in the Criminal Procedure Code. Because every act of forced effort such as arrest, detention, search, confiscation, prosecution and so on that is carried out contrary to law and legislation is an act of rape and deprivation of human rights.

The implementation of pretrial is the authority of the District Court to examine and decide on several matters which are the reasons for the submission of a pretrial before a trial. This pretrial enforcement authority arises because of a pretrial request submitted by the suspect, the suspect's family, or his attorney (legal advisor) regarding the legality of an arrest, detention and compensation and rehabilitation (Article 79 jo Article 81 of the Criminal Procedure Code) and submitted by a legal investigator or not the cessation of the investigation and the cessation of the prosecution by the Public Prosecutor, and can also be submitted by the Prosecutor for the cessation of the investigation and prosecution (Article 80 of the Criminal Procedure Code).

Based on the research, according to the author, it is examined by the Progressive Law theory that the Judge in examining, adjudicating and deciding a case before him must first use the written law first, namely the laws and regulations, but if the laws and regulations are apparently not enough or it is not appropriate with the problem in a case, then the judge will find and find his own law from other sources of law such as jurisprudence, doctrine, treaty, custom, or unwritten law. The judge presiding over the a quo case also still considers the investigator as authorized to make a subjective interpretation regarding whether or not a person can be detained. Even the judge thought he was still allowed; only with subjective conditions, the investigator justifies detention. This consideration is wrong, because such considerations actually open up opportunities for investigators to violate the rights of the suspect. The pretrial judge should have understood that the Constitutional Court's decision had shifted the subjective conditions of arrest and the subjective conditions of detention to the conditions that had to be objectified through two pieces of evidence and examination of the prospective suspect before he was subjected to forced acts of arrest and detention.

\subsection{Comparison of the Implementation of the Pretrial Process Before and After the Decision of the Constitutional Court Number: 21 / PUU-XII / 2014 In the Batang State Court}

2.3.1. Object of Pretrial Before the Constitutional Court's Decision Number: 21 / PUUXII / 2014 has been enacted. 
Basically the pretrial object contained in the Criminal Procedure Code before the Constitutional Court's ruling, is quite simple and not difficult to interpret, anything that becomes the object of pretrial. For more details, so as not to be biased, then the entire contents of the article related to the pretrial object are quoted:

Article 1 number 10 of the Criminal Procedure Code states: pretrial is the authority of the District Court to examine and decide:

- Whether an arrest or detention is valid or not;

- The validity of the investigation or the prosecution;

- Requests for compensation or rehabilitation by the suspect or his family or other parties or proxies whose cases have not been submitted to the court.

Based on what was formulated in Article 1 number 10 of the Criminal Procedure Code, again emphasized in Article 77 of the Criminal Procedure Code, which confirms: The District Court has the authority to examine and decide upon it, in accordance with the provisions stipulated in this Law concerning:

- The legitimacy of arrest, detention, cessation of investigation, or cessation of prosecution;

- Compensation or rehabilitation for a person whose criminal case is terminated at the level of investigation or prosecution.

Based on the decision of the Pre-trial District Court of Batang Number: 01 / Pid.Pra / 2013 / PN.BATANG. The subject matter of the petition of the defendant is the cessation of detention of the Police Report No. LP / 51 / XI / 1999 received on November 15, 1999 concerning the falsification of a land purchase statement made and signed by the Head of Kebondalem Village (Mr. Suprayitno), the applicant considered the SP Decree Letter. BUT 01/111 / 2013 Criminal Investigation issued by the Head of the Batang District Police by stopping the investigation of falsified criminal statements is not groundless because the evidence is sufficient with the testimony of living witnesses. According to the author's analysis of the pretrial object before the entry into force of the Constitutional Court Decision Number: 21 / PUU-XII / 2014 is still in accordance with article 77 of the Criminal Procedure Code,

\subsubsection{Object of Pretrial After the Constitutional Court Decision Number: 21 / PUU-XII /} 2014 comes into effect

Criminal law adheres to the search for truth that is materil. A search for the real truth, without the slightest hesitation. That is why the criminal law justifies the principle in dubio proreo: in doubt, the most favorable punishment is for the defendant.

With the starting point of the nature of the search for material truth, then leaning on the Constitutional Court Decision Number 21 / PUU-XII / 2014 in his consideration, he has shifted the terms of the pretrial petition along with each of his objects to adhere to the due process of the model than the crime control model which is more dominant in regard to the acceleration of the case than the search for material truth.

It is examined by the theory of Law Enforcement that legal events or laws and regulations are not merely seen or interpreted from the formal legal aspects based on the sound of the text alone, but must also be seen from the factors underlying the events or disputes that arise, what is the root cause of the intervention the politics that gives birth to a decision is issued, and the actions of the impact of that decision 
are considered for the process of law enforcement and justice in the future. In the judicial practice of the Constitutional Court's decision, it provides protection for someone who has experienced a wrong legal process when he is named as a suspect. In the provisions of Article 8 of Law 39/1999 on Human Rights it is regulated that "Protection, promotion, enforcement and fulfillment of human rights are primarily the responsibility of the government. This means that the Court took a role in fulfilling human rights through its decision as part of constitutional responsive efforts. One element of legal protection emphasized through this decision is legal certainty that investigators must carry out investigative actions in accordance with applicable legal procedures.

\section{Closing}

\subsection{Conclusion}

- The Basic Authority of the Court to Check and Resolve a Pretrial Claim is: Article 77 of the Criminal Procedure Code (KUHAP) states that a district court has the authority to examine and decide in accordance with the provisions stipulated in this law concerning: Legitimate arrest or detention, cessation of investigation or cessation of prosecution; Compensation and / or rehabilitation for people whose criminal cases have been stopped at the level of investigation or prosecution;

In this provision it is clear that what can be applied for pretrial is legal or not arrest, detention, cessation of investigation or prosecution, and compensation and or rehabilitation. However, in practice, the court granted the pretrial petition outside of what was stipulated in article 77 of the Criminal Procedure Code.

- The legal force of the pretrial decision regarding the illegality of the determination of the suspect that the determination of the suspect as part of the investigation process that is deprivation of human rights, then the determination of the suspect by the investigator is an object that can be sought protection through pretrial pretrial law efforts. After the Constitutional Court Decision Number 21 / PUU-XII / 2014, the pretrial petition for determining a suspect has a legal basis to be submitted to the court but there are special characteristics of the pretrial submission related to the decision of the suspect. So that the legal force of the pretrial ruling regarding the illegitimate determination of the suspect has a clear legal basis.

Although the Constitutional Court's verdict is indeed final and binding and binding and no remedy can be made (it is the final decision). However, that does not mean automatically changing the Criminal Procedure Code. Because these changes can only be made by official institutions appointed by the State, namely the President and the Parliament which are the state's decision. The implication that occurs is opening up the space for all parties who have been designated as suspects to submit a pretrial so that the rules regarding the change in the object of a pretrial suit are regulated in regulations in the form of a law or its equivalent.

- The pretrial object prior to the enactment of the Constitutional Court Decision Number: 21 / PUU-XII / 2014, consists of: whether or not a legal action is forced (in the form of an arrest, detention, search and seizure); the validity of the termination 
of the investigation or the termination of the prosecution; and compensation or rehabilitation by the suspect or his attorney or his family for acts of force or cessation of investigation / prosecution for which the case was not brought to court. In the pretrial object before the Constitutional Court's ruling, the forced action in the form of arrest and detention still allows the subjective conditions of arrest and the subjective conditions of detention.

The object of pretrial after the enactment of the Constitutional Court Decision Number: 21 / PUU-XII / 2014, namely the addition of the pretrial object for the validity of determining the suspect. In addition, the implications of the a quo Constitutional Court ruling also affect the validity of arrest and the validity of detention must be based on the objective requirements of the investigator; through two pieces of evidence and an examination of a prospective suspect in order to fulfill the allegation of "preliminary evidence, sufficient preliminary evidence, and sufficient evidence".

\subsection{Suggestion}

- A revision of the Criminal Procedure Code is needed. Another option is to enter a regulation regarding the expansion of the pretrial object into the RKUHAP and immediately ratify the RKUHAP because the change can only be made by official institutions namely the President and the Parliament.

- The participation of the community, law enforcement officials and the government, especially the DPR, is needed to help carry out the pretrial function in the form of supervision of acts or forced efforts to prevent violations of human rights.

- To prevent most of the mindset of Indonesian judges who according to the author are more compliant and feel bound to written rules such as the Law or its equivalent rather than internal rules such as SEMA, so that the rules regarding the expansion of the pretrial object can be regulated in regulations in the form of Law or its equivalent.

\section{References}

[1] Department of Justice. Decree of the Minister of Justice Concerning Guidelines for Implementing the Criminal Procedure Code. Minister of Justice Decree No. M.01.07.03 of 1983, as written by Adnan Buyung Nasution in his writing about pretrial vs commissioner judge in the National Law Commission Newsletter

[2] L\&J Law Firm, 2009, Bila Anda Menghadapi Masalah Hukum (Pidana), Forum Sahabat

[3] M. Yahya Harahap, SH. Pembahasan Permasalahan dan Penerapan KUHAP Penyidikan dan Penuntutan.Sinar Grafika. Jakarta, 2013

[4] Decision of the Constitutional Court Number: 21 / PUU-XIII / 2014

[5] Act No. 2 of 2002 concerning the Indonesian National Police

[6] Act No. 48 of 2009 concerning Judicial Power

[7] Act No. 8 of 1981 concerning Criminal Procedure Law (KUHAP) 